Кругляк Ю. М.

УДК 582.711.26:58.032.3

ВОДНИЙ РЕЖИМ ЛИСТКІВ РОСЛИН РОДУ DEUTZIA THUNB. У ЗВ'ЯЗКУ З ЇХ ПОСУХОСТІЙКІСТЮ В УМОВАХ ІНТРОДУКЦІї У ПІВНІЧНІЙ ЧАСТИНІ ЛІСОСТЕПУ УКРАЇНИ

Ю. М. КРУГЛЯК, кандидат біологічних наук

Національний ботанічний сад ім. М.М. Гришка НАН Украӥни

E-mail: ulija_kr@ukr.net

https://doi.org/10.31548/dopovidi2020.04.004

Анотація. Дейції - декоративні і стійкі до техногенного забруднення кущьові рослини, які широко використовуються в озелененні. Для таких рослин важливим $\epsilon$ стійкість до різних несприятливих факторів зовнішнього середовища, зокрема до посухи. Візуальна оцінка польової посухостійкості рослин не завжди є достатньою, до того ж вона не відображає найменших реакиій рослинного організму на фізіологічному рівні. Тому нами було вирімено встановити ступінь посухостійкості рослин видів і культиварів роду Deutzia iз колекції дендрарію Національного ботанічного саду ім. М.М. Гришка НАН України шляхом вивчення водного режиму листків. Дослід проводили у другій декаді червня 2018 р. у період активного росту пагонів. Йому передував тривалий період без опадів. Листки всіх досліджуваних рослин роду Deиtzia досить інтенсивно втрачали воду протягом доби, але потім відновлювали ї̈

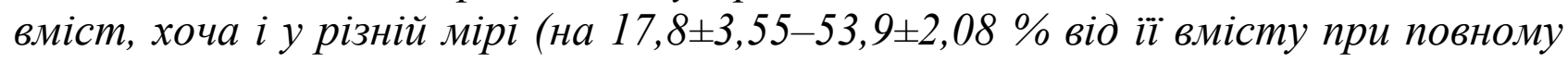
водонасиченні) За результатами цьього дослідження найбільш стійкими до посухи виявились рослини D. gracilis i D. ×elegantissima. Найменш стійкими до посухи є рослини D. schneideriana, D. mollis $i$ D. scabra. Загалом рослини роду Deиtziа є чутливими до дефіциту вологи у трунті, але вони здатні відновлювати втрачену після тривалої посухи воду.

Ключові слова: Deutzia Thuпb., листок, водний режим, посухостійкість

Актуальність. Deutzia Thunb. південноголарктичний американоазійський рід. Природним ареалом рослин даного роду $\epsilon$ території Східної і Південно-Східної Азії до крайніх західних відрогів Гімалаїв та Північної Америки (Мексика), тому для України вони є інтродуцентами $[1,11]$. Інтродукція цих рослин до України почалася ще з середини XIX ст. Вони дуже декоративні і достатньо стійкі до умов техногенного забруднення [9]. Однією з вимог до рослин, які придатні для використання в озелененні є стійкість до посухи.

Візуальна оцінка польової посухостійкості рослин за відомими шкалами $[5,7,8]$ не завжди $\epsilon$ достатньою для практики. 32008 p. нами велись спостереження за дейціями із колекції дендрарію Національного ботанічного саду ім. М.М. Гришка НАН України (НБС). Польова посухостійкість досліджуваних рослин за візуальними 
Кругляк Ю. М.

ознаками була оцінена нами у 7 балів за шкалою В.М. Меженського [7], що не відображає найменших змін у рослинах на фізіологічному рівні як реакції на дефіцит влоги у грунті. Хоча, навіть у межах одного балу шкали візуальної оцінки на фізіологічному рівні у різних рослин можуть спостерігатися певні відмінності.

Під час дії різного роду стресів, зокрема дефіциту вологи, у рослинах відбуваються адаптаційні процеси, починаючи від молекулярного рівня i закінчуючи пристосуваннями на рівні організму. Знання цих процесів важливо як для цілісного розуміння стійкості рослини до стресу, так і для керування процесами росту і розвитку $[10,12]$.

Для визначення потенційної посухостійкості рослин достатньо ефективним ми вважаємо метод діагностики за станом листкової пластинки, що передбачає використання лабораторного методу в'янення [6]. Цей метод моделює умови грунтової посухи.

Аналіз останніх досліджень i публікацій. У 1994 - 1999 рр. велись спостереження за рослинами роду Deutzia колекціï дендрарію НБС. Протягом цього періоду була оцінена польова посухостійкість рослин за візуальною шкалою [9]. Також проводились дослідження стійкості рослин деяких видів данного роду в умовах Степового Придніпров'я. Була оцінена польова посухостійкість рослин у цьому регіоні і проведені дослідження стійкості за допомогою фізіологічних методів [2-4].

Метою дослідження було встановити ступінь посухостійкості рослин видів і культиварів роду Deutzia iз колекції дендрарію НБС шляхом вивчення водного режиму листків.

Матеріали i методи. Водний режим листків рослин роду Deutzia досліджували ваговим методом за М.Д. Кушніренко [6]. Дослід проводили у другій декаді червня 2018 р. у період активного росту пагонів. Досліду передував тривалий період без опадів (21 день). Вологість повітря зменшувалась до $30 \%$, а максимльна температура становила $+30^{\circ} \mathrm{C}$.

Об’єктами нашого дослідження були рослини таких видів i культиварів роду Deutzia iз колекції дендрарію НБС: D. ×elegantissima (Lemoine) Rehd., D. gracilis Sieib. et Zucc., D. ×magnifica (Lemoine) Rehd., D. mollis Duthie, D. ×rosea (Lemoine) Rehd., D. scabra Thunb., D. schneideriana Rehd., D. scabra 'Candidissima', D. scabra 'Plana', D. longifolia 'Sessiliflora'. У природі рослини цих видів зростають у Центральному Китаї (D. mollis, D. schneideriana) і Японії (D. gracilis, D. scabra) [1, 11]. Вік досліджуваних рослин становить близько 60 років.

Зразки відбирали у другій половині дня за умов сонячної погоди iз центральної частини пагонів 
Кругляк Ю. М.

середньої третини крон модельних кущів. Відбирали по 10 листків у двох повторностях. Зразки вміщували у целофанові пакети i доставляли у лабораторію. Зразки листків зважували на електронних вагах ТВТВ 404316 НЕ з точністю до 0,05 г. Після першого зважування зразки протягом 12 годин доводили до повного водонасичення i знову зважували. Після цього рослини розміщували на фільтрувальному папері в умовах постійної температури i вологості повітря. Наступні зважування проводили через 2, 4, 6, 12, 24 години, після чого зразки знову доводили до повного насичення водою і знову зважували. Потім листки висушували до абсолютно сухого стану при температурі $105^{\circ} \mathrm{C}$ у сушильній шафі i знову зважували.

\section{Розрахунковим}

ШЛЯХОМ визначали вміст загальної води, водний дефіцит, водоутримуючу здатність листків протягом доби, відносну тургоресцентність листків та їхню водопоглинаючу здатність після в'янення.

Результати дослідження та обговорення. Отримані результати свідчать, що листки всіх досліджуваних рослин роду Deutzia досить інтенсивно втрачали воду протягом доби (рис. 1). Вже через 2 години після початку в'янення листки втратили від $23,8 \pm 0,22 \%$ до $52,4 \pm 2,42 \%$ від загальної маси, а через 4 години - від $37,1 \pm 0,95 \%$ до

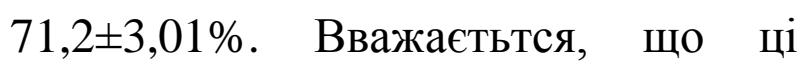
втрати у масі листків відбуваються за рахунок випаровування води.

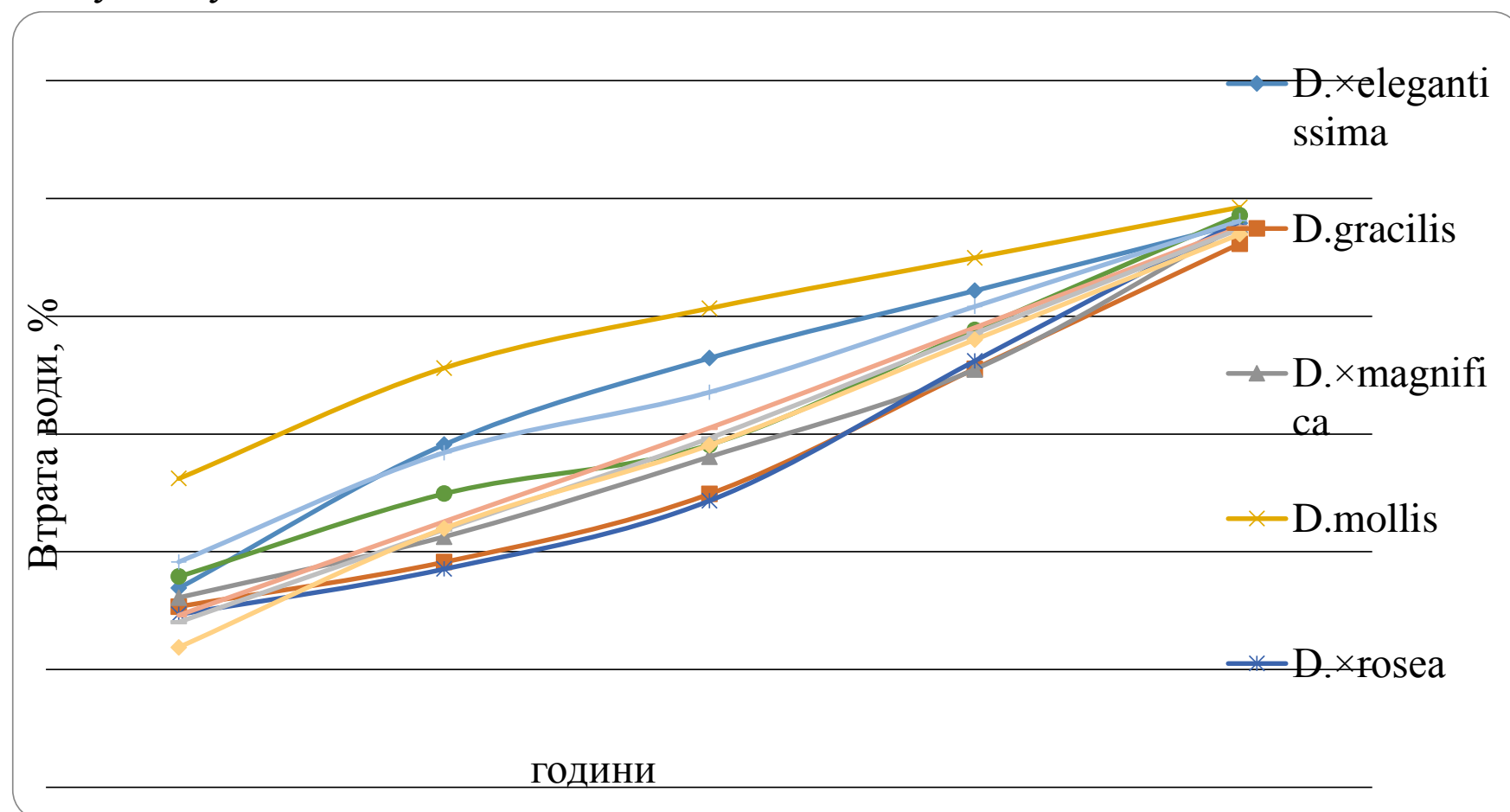

Рис. 1. Динаміка втрати води листками рослин роду Deutzia протягом доби 
Кругляк Ю. М.

Через 6 годин після початку в'янення втрати води листками становили від $49,8 \pm 5,78 \%$ до $81,3 \pm 2,54 \%$, а через 12 годин $71,0 \pm 9,34 \%-89,9 \pm 3,79 \%$. Вже через 24 години листки досліджуваних рослин втратили від 92,3 $\pm 0,3$ \% до $98,5 \pm 1,52$ \% води. Менш інтенсивно втрачали воду листки D. gracilis, a найбільш інтенсивно - D. mollis.

Вміст загальної води у листках дейцій різних таксонів варіював від $77,8 \pm 2,52 \%$ уD. ×elegantissima до $84,2 \pm 0,08 \%$ у D. scabra від загальної маси листків (табл. 1). Значною мірою варіював показник водного дефіциту.
Найменші його значення мали листки D. schneideriana $(1,1 \pm 0,06 \%)$ i D. ×magnifica $(1,6 \pm 0,25 \%)$. Найбільший дефіцит води спостерігався у D. gracilis $(17,3 \pm 1,26 \%)$.

Показник відносної тургоресцентності вказує на те, що вміст води у листках усіх досліджуваних рослин одразу після збору зразків був достатньо високим по відношенню до іiі вмісту при повному водонасиченні: від $82,7 \pm 1,26 \%$ у D. gracilis до

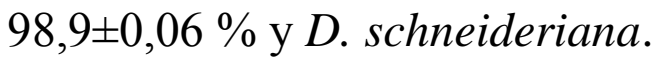

\section{1. Водний режим листків рослин роду Deutzia}

\begin{tabular}{|l|c|c|c|c|}
\hline Вид, культивар & $\begin{array}{c}\text { Загальна } \\
\text { вода, \% }\end{array}$ & $\begin{array}{c}\text { Дефіцит } \\
\text { води, \% }\end{array}$ & $\begin{array}{c}\text { Відносна } \\
\text { тургоресцентність, \% }\end{array}$ & $\begin{array}{c}\text { Водопоглинаюча } \\
\text { здатність, \% }\end{array}$ \\
\hline D. ×elegantissima & $77,8 \pm 2,52$ & $2,9 \pm 0,60$ & $97,1 \pm 0,60$ & $41,1 \pm 8,02$ \\
\hline D. gracilis & $79,7 \pm 1,10$ & $17,3 \pm 1,26$ & $82,7 \pm 1,26$ & $53,9 \pm 2,08$ \\
\hline D. ×magnifica & $79,0 \pm 0,51$ & $1,6 \pm 0,25$ & $98,4 \pm 0,25$ & $22,5 \pm 0,92$ \\
\hline D. mollis & $81,3 \pm 1,34$ & $7,7 \pm 1,81$ & $92,1 \pm 1,81$ & $18,7 \pm 2,54$ \\
\hline D. ×rosea & $80,0 \pm 0,72$ & $4,3 \pm 0,32$ & $95,7 \pm 0,32$ & $25,5 \pm 0,47$ \\
\hline D. scabra & $84,2 \pm 0,08$ & $8,3 \pm 1,41$ & $91,7 \pm 1,41$ & $17,8 \pm 3,55$ \\
\hline D. schneideriana & $84,0 \pm 0,50$ & $1,1 \pm 0,06$ & $98,9 \pm 0,06$ & $19,6 \pm 2,03$ \\
\hline $\begin{array}{l}\text { D. scabra } \\
\text { 'Candidissima' }\end{array}$ & $81,2 \pm 0,62$ & $5,0 \pm 3,69$ & $95,0 \pm 3,69$ & $23,1 \pm 5,63$ \\
\hline D. scabra 'Plana' & $80,7 \pm 0,19$ & $5,1 \pm 0,63$ & $94,9 \pm 0,63$ & $33,9 \pm 6,26$ \\
\hline $\begin{array}{l}\text { D. longifolia } \\
\text { 'Sessiliflora' }\end{array}$ & $82,6 \pm 0,29$ & $6,5 \pm 2,33$ & $93,5 \pm 2,33$ & $26,9 \pm 5,36$ \\
\hline
\end{tabular}

Найгірше відновили вміст води після в'янення листки D. scabra, D. mollis i D. schneideriana, на що вказує показник водопоглинаючої здатності. Вони увібрали лише $17,8 \pm 3,55 \%, 18,7 \pm 2,54 \%$ i $19,6 \pm 2,03 \%$ води від iii вмісту при повному водонасиченні відповідно. Найкраще відновили вміст води листки D. gracilis - на 53,9 $\pm 2,08 \%$ від ii вмісту при повному водонасиченні. Дещо менше, але теж на достатньому рівні відновився вміст води у листках D. ×elegantissima - на 41,1 $\pm 8,02 \%$.

\section{Висновки і перспективи.} Аналіз водного режиму листків дозволив нам визначити потенційну посухостійкість рослин роду Deutzia. За результатами цього дослідження найбільш стійкими до посухи серед 
Кругляк Ю. М.

досліджених рослин ми вважаємо D. gracilis i D. ×elegantissima. $\mathrm{y}$ листках D. gracilis хоча і був найбільший дефіцит води на початку досліду, але вони втратили найменше вологи протягом 24 годин в'янення i водопоглинаюча здатність у них була найкращою. $\mathrm{y}$ листках D. ×elegantissima дефіцит води був одним 3 найменших. Протягом 24 годин в'янення вони втратили дещо більше води, ніж D. gracilis, але водопоглинаюча здатність у них була значно кращою, ніж у решти видів.

Найменш стійкими до посухи виявились рослини D. schneideriana, D. mollis i D. scabra. Листки рослин першого виду хоча і мали найменший дефіцит води на початку досліду, але протягом 24 годин в’янення втратили багато води i водопоглинаюча здатність у них була однією 3

\section{Список використаних джерел}

1. Заиконникова Т.И. Дейции декоративные кустарники. Монография рода Deutzia Thunb. Москва; Ленинград: Наука, 1966. 140 с.

2. Зайцева И.А. Водный баланс растений семейства Saxifragaceae в условиях Степного Приднепровья. Вісник Дніпропетровського університету. Біологія, екологія. 2006. № 14 (2). С. 72-78.

3. Зайцева И.А. Оценка полевой засухоустойчивости древесных интродуцентов. Фальи Фейнівські читання: зб. наук. праць. Херсон, 2007. С. 128-131.

4. Зайцева И.А. Энтропийные характеристики устойчивости растений: информационный и термодинамический подходы. Екологія та ноосферологія. 2012. Т. 23, № $1-2$. С. 32-40.

5. Кохно Н.А., Курдюк А.М. Теоретические основы и опыт интродукции растений на Украине. Киев: Наукова думка, 1994. 185 c. найслабших. Листки рослин D. mollis i D. scabra на початку досліду мали одні 3 найбільших дефіцитів води, протягом 24 годин в'янення втратили найбільше води i водопоглинаюча здатність у них була найслабшою. Рослини решти видів за результатами цього досліду мають середню стійкість до посухи.

Загалом рослини роду Deutzia є чутливими до дефіциту вологи у грунті, але вони здатні швидко відновлювати втрачену після тривалої посухи воду.

Також даним експериментом показано, що навіть у межах одного балу шкали візуальної оцінки польової посухостійкості рослин на нижчих рівнях організації рослинного організму (тканинному, клітинному) відбуваються значні зміни у водному режимі листків.

6. Кушниренко М.Д., Гончарова Э.Л., Бондарь Е.M. Методы изучения водного обмена и засухоустойчивости плодовых растений. Кишинёв: Штиинца, 1970. 80 с.

7. Меженський В.М. Уніфікування шкал оцінок, що застосовуються при інтродукції деревних рослин. Інтродукція рослин. 2007. № 4. С. 26-37.

8. Пятницкий С.С. Практикум по лесной селекции. Москва: Сельхозиздат, $1961.271 \mathrm{c}$.

9. Счепицкая Т.С. Биологические особенности видов семейства Hydrangeaceae Dum. в связи с интродукцией в Правобережной Лесостепи Украины: дис. ... канд. биол. наук: 03.00.05 / Нац. бот. сад им. Н.Н. Гришко. Киев, 2000. 196 с.

10. Chaves M.M., Maroco J.P., Pereira J.S. Understanding plant responses to drought from genes to the whole plant. Functional Plant Biology. 2003. 30, P. 239-264. doi: 10.1071/FP02076 
Кругляк Ю. М.

11. Flora of China. Missouri BGP. 2001. Vol. 8. P. 395-403.

12. Varshney R.K., Tuberosa R., Tardieu F. Progress in understanding drought tolerance: from alleles to cropping systems. Journal of Experimental Botany. 2018. Vol. 69, No. 13. P. 3175 - 3179. doi: 10.1093/jxb/ery 187

\section{References}

1. Zaikonnikova, T.I. (1966). Dejcii dekorativnye kustarniki. Monografiya roda Deutzia Thunb. [Deutzia - ornamental shrubs. Monograph of Deutzia Thunb. genus]. M.,L.: Nauka, 140.

2. Zaitseva, I. A. (2006). Vodnyj balans rastenij semejstva Saxifragaceae v usloviyah Stepnogo Pridneprovya [Water balance in plants of family Saxifragaceae under conditions of Steppe Dnieper region]. Bulletin of Dnipropetrovsk University. Biology, ecology, № 14 (2), 72-78.

3. Zaitseva, I. A. (2007). Ocenka polevoj zasuhoustojchivosti drevesnyh introducentov [Assessment of field drought tolerance of introduced woody plants]. Faltz Fein reading. Kherson, 128-131.

4. Zaitseva, I. A. (2012). Entropijnye harakteristiki ustojchivosti rastenij: informacionnyj i termodinamicheskij podhody [Information and thermodinamic entropy as caracteristics of plant stability]. Ecology and noospherology, Vol. 23, № $1-2$, 32-40.

5. Kohno, N.A., Kurdyuk, A.M. (1994). Teoreticheskie osnovy i opyt introdukcii rastenij na Ukraine [Theoretical foundations and experience of plant introduction in Ukraine]. K.: Naukova dumka, 185.
6. Kushnirenko, M.D., Goncharova, E.L., Bondar, E.M. (1970). Metody izucheniya vodnogo obmena i zasuhoustojchivosti plodovyh rastenij [Methods for studying water metabolism and drought tolerance of fruit plants]. Kishinev: Shtiinca, 80.

7. Mezhensky, V.M. (2007). Unifikuvannia shkal otsinok, shcho zastosovuiutsia pry introduktsii derevnykh roslyn [Unification of rating scales used in the introduction of woody plants]. Plants introduction, № 4, 26-37.

8. Pyatnitsky, S.S. (1961). Praktikum po lesnoj selekcii [Forest breeding workshop]. M.: Selhozizdat, 271.

9. Schepitskaya, T.S. (2000). Biologicheskie osobennosti vidov semejstva Hydrangeaceae Dum. v svyazi s introdukciej v Pravoberezhnoj Lesostepi Ukrainy [Biological features of species of the Hydrangeaceae Dum. family in connection due to their introduction of the Right-Bank Forest-Steppe of Ukraine]. Kiev, 196.

10. Chaves, M.M., Maroco, J.P., Pereira, J.S. (2003) Understanding plant responses to drought - from genes to the whole plant. Functional Plant Biology, 30, 239-264. doi: 10.1071/FP02076.

11. Flora of China. Missouri BGP (2001), Vol. 8, 395-403.

12. Varshney, R.K., Tuberosa, R., Tardieu, F. (2018). Progress in understanding drought tolerance: from alleles to cropping systems. Journal of Experimental Botany, Vol. 69, No. 13, 3175 - 3179. doi: $10.1093 / j x b / e r y 187$.

\section{ВОДНЫЙ РЕЖИМ ЛИСТЬЕВ РАСТЕНИЙ РОДА DEUTZIA THUNВ. В СВЯЗИ С ИХ ЗАСУХОУСТОЙЧИВОСТЬЮ В УСЛОВИЯХ ИНТРОДУКЦИИ В СЕВЕРНОЙ ЧАСТИ ЛЕСОСТЕПИ УКРАИНЫ Ю. М. Кругляк}

Аннотация. Дейции-декоративные и устойчивые $\kappa$ техногенному загрязнению кустарниковые растения, которые иироко используются $в$ озеленении. Для таких растений важной является устойчивость к разного рода неблагоприятныл факторам внешней среды, в частности к засухе. Визуальная оченка полевой засухоустойчивости растений не всегда является достаточной, $\kappa$ тому же она не отображает наименьших реакиий растительного организма на физиологическом уровне. Поэтому было решено определить степень засухоустойчивости растений видов и культиварорв рода Deиtzia из коллекичи 
Кругляк Ю. М.

дендрария Национального ботанического сада им. Н.Н. Гришко НАН Украиньл путем изучения водного режима листьев. Исследование проводили во второй декаде июня 2018 г. в период активного роста побегов. Ему предиествовал длительный период без осадков. Листья всех исследуемых растений рода Deutzia довольно интенсивно теряют воду на протяжении суток, но потом возобновляют ее содержание, хотя и в разной степени (на 17,8 $\pm 3,55-$

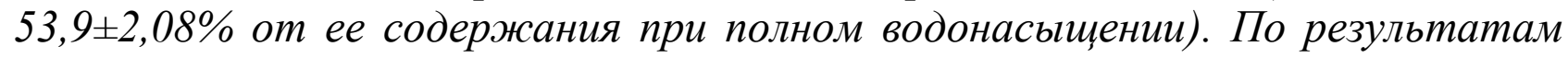
этого исследования наиболее устойчивыми к засухе оказались растения D. gracilis $i$ D. ×elegantissima. Наименее устойчивыми $к$ засухе являются pacmения D. schneideriana, D. mollis i D. scabra. B общем растения рода Deutzia чувствительны к дефициту воды в почве, но они способнь возобновлять потерянную после длительной засухи воду.

Ключевые слова: Deutzia Thuпb., лист, водный режим, засухоустойчивость

\title{
WATER REGIME OF THE LEAVES OF PLANTS OF DEUTZIA THUNB. GENUS DUE TO THEIR DROUGHT TOLERANCE IN THE CONDITIONS OF INTRODUCTION IN THE NORTHEN PART OF THE FOREST-STEPPE OF UKRAINE Yu. M. Krugliak
}

\begin{abstract}
Deutzias are ornamental and resistant to technogenic pollution shrub plants that are widely used in landscaping. Resistance to various adverse environmental factors, in paticular to drought, is important for such plants. Visual assessment of field drought tolerance of plants is not always sufficient; moreover, it does not reflect the smallest reactions of the plant at the physiological level. Therefore, it was decided to determine the degree of drought tolerance of plant species and cultivars of the genus Deutzia from the arboretum collection of the M.M. Gryshko National Botanical Garden of the NAS of Ukraine by studying the water regime of leaves. The study was carried out in the second decade of June 2018 during the period of active growth of shoots. It was preceded by a long period without precipitation. Leaves of all stadied plants of the genus Deutzia quite intensively lose water during twenty-four hours, but then they resume its content, although to a different degree (by 17.8 $\pm 3.55-53.9 \pm 2.08 \%$ of its content when fully saturated). According to the results of this study, D. gracilis and D. × elegantissima were most resistant to drought. The least resistant to drought are D. schneideriana, D. mollis and D. scabra. In general, plants of the genus Deutzia are sensitive to water deficiency in the soil, but they are able to renew water lost after prolonged drought.
\end{abstract}

Key words: Deutzia Thunb., leaf, water regime, drought tolerance 